\title{
$\beta$-casein gene polymorphism permits identification of bovine milk mixed with bubaline milk in mozzarella cheese
}

Antonio R. Otaviano, André Luis F. Lima, Monyka M.M. Laureano, Janete A.D. Sena, Lúcia G. de Albuquerque and Humberto Tonhati

Departamento de Zootecnia, Faculdade de Ciências Agrárias e Veterinárias, Universidade Estadual de São Paulo “Júlio de Mesquita Filho”, Jaboticabal, SP, Brazil.

\begin{abstract}
Mozzarella cheese is traditionally prepared from bubaline (Bubalus bubalis) milk, but product adulteration occurs mainly by addition of or full substitution by bovine milk. The aim of this study was to show the usefulnes of molecular markers to identify the admixture of bovine milk to bubaline milk during the manufacturing process of mozzarella cheese. Samples of mozzarella cheese were produced by adding seven different concentrations of bovine milk: $0 \%$, $1 \%, 2 \%, 5 \%, 8 \%, 12 \%$ and $100 \%$. DNA extracted from somatic cells found in cheese were submitted to PCR-RFLP analysis of casein genes: $\alpha$-s1-CN - CSN1S1 that encompasses 954 bp from exon VII to intron IX (Alu I and Hinf I), $\beta$-CN - CSN2 including 495 bp of exon VII (Hae III and Hinf I), and א-CN - CSN3, encompassing 373 bp of exon IV (Alu I and Hind III). Our results indicate that Hae III-RFLP of CSN2 exon VII can be used as a molecular marker to detect the presence of bovine milk in "mozzarella" cheese.
\end{abstract}

Key words: casein, gene polymorphism, mozarella, cheese authentication, PCR-RFLP.

Received: August 6, 2007; Accepted: July 21, 2008.

Mozzarella cheese has its origin in Italy where it is traditionally manufactured from bubaline (Bubalus bubalis) milk. The most commonly employed production process of mozzarella cheese is a traditional technique where bacterial fermentation of milk induces $\mathrm{pH}$ reduction and curd precipitation (Chapman et al., 1981). Nowadays, many countries that have a considerable number of buffalo cows widely use the milk of these animals for mozzarella cheese production.

Some dairy products can be adulterated by milk admixture from different species in order to maximize profit. Certification is, thus, a way to guarantee cheese quality and to protect consumers against fraudulent producers. Bubaline breeders demand high precision technology to validate milk origin to assure that only bubaline milk is present in the composition of the manufactured product. The most common type of adulteration in the manufacture of mozzarella cheese is the addition or full replacement of bubaline milk by bovine milk. Consequently, several methods have been developed to detect milk mixture in these products.

Send correspondence to Antonio Roberto Otaviano. Departamento de Zootecnia, Faculdade de Ciências Agrárias e Veterinárias, Universidade Estadual de São Paulo "Júlio de Mesquita Filho", Jaboticabal, Via de Acesso Prof. Paulo Donato Castellane, s/n, Prédio II, 14884-900 Jaboticabal, SP, Brazil. E-mail: aroctaviano@ yahoo.com.br.
Methods based on electrophoresis and chromatography include isoelectric focusing (Moio et al., 1989), high-performance liquid chromatography (Visser et al., 1991; Veloso et al., 2002; Enne et al., 2005), nuclear magnetic resonance spectroscopy (Andriotti et al., 2000), and also hydrophobic interaction chromatography (Bramanti et al., 2003). However, these methods present limitations due to time intensive protocols and/or high costs.

An alternative way to detect milk mixtures is the use of molecular markers to identify the DNA of different species (Bardin et al. 1994; Branciari et al., 2000; Rea et al., 2001; Bottero et al., 2002; Leoparelli et al., 2007). Here we describe a relatively rapid and simple method to identify admixtures of bovine milk to bubaline milk, by extracting DNA directly from Mozzarella cheese and analyzing a $\beta$-casein gene polymorphism.

Samples of "pasta filata" mozzarella cheese were produced using $7 \mathrm{~L}$ of milk according to the methodology developed by Kuo et al. (2001). The samples were prepared in the "Laticínio White Milk" facility (Marilia, SP, Brazil), using bovine milk mixed with bubaline milk at concentrations of $0 \%, 1 \%, 2 \%, 5 \%, 8 \%, 12 \%$ and $100 \%$ (T1-T7). Bovine milk was obtained from a herd of different milky breeds (Holstein, Brown-Swiss, Jersey, and the Brazilian native breeds: Gir, Guzerá and Girolanda) with the intention to have as many $\beta$-casein gene variants as possible. 
Genomic DNA was extracted from 30 samples of each bovine milk concentration, following a methodology adapted by the authors. Each sample consisted of $25 \mathrm{mg}$ mozzarella cheese, $200 \mu \mathrm{L}$ Nonidet P40 (12.5\%), $1 \mathrm{~mL}$ TKM1 buffer [Tris-HCl (1 M) pH 7.6; KCl (1 M) and EDTA (0.1 M) pH 8.0] and $200 \mu \mathrm{L} 20 \%$ SDS. After heating the sample in a water bath at $55^{\circ} \mathrm{C}$ for $1 \mathrm{~h}, 400 \mu \mathrm{L} \mathrm{NaCl}$ (6 M) were added, followed by centrifugation at 14,840 $\mathrm{xg}$ for $15 \mathrm{~min}$ at $31^{\circ} \mathrm{C}$. A $700 \mu \mathrm{L}$ aliquot of the precipitate was transferred to a new tube, and $700 \mu \mathrm{L}$ of cooled absolute ethanol were added, followed by centrifugation at 14,840 $x g$ for $15 \mathrm{~min}$ at $4{ }^{\circ} \mathrm{C}$. The residual solution was then discarded, and $100 \mu \mathrm{L}$ of TE buffer [Tris- $\mathrm{HCl}(1 \mathrm{M}) \mathrm{pH} 8.0$ EDTA (0.1 M) pH 8.0] 10:1 were added.

DNA amplification was performed using primers for the casein genes: $\alpha$-s1-CN - CSN1S1 (A 900 F 5'-ATGT TGGGCACCTACTGAC-3' and A I8 R 5'-GGATAGA GCTACATACATAGT-3') that amplifies a 954 bp fragment from exon VII to intron IX; $\beta-\mathrm{CN}-\operatorname{CSN} 2$ (B F 5'-GATGAACTCCAGGATAAAATC-3' and B R 5'-A ATAATAGGGAAGGGTCCCCG-3') that amplifies a 495 bp fragment of exon VII; and $\kappa-\mathrm{CN}-C S N 3$ (K1 5'-CACGTCACCCACACCCACATTTATC-3' and K2 5'-TAATTAGCCATTTCGCCTTCTCTGT-3') that amplifies a $373 \mathrm{bp}$ fragment of exon IV. PCR amplifications were performed in a final volume of $25 \mu \mathrm{L}$ containing $100 \mathrm{ng}$ of DNA, $0.5 \mu \mathrm{M}$ of each primer, $1 \mathrm{X}$ PCR "buffer" (10 mM Tris- $\mathrm{HCl} \mathrm{pH} \mathrm{9.0,} 1.5 \mathrm{mM} \mathrm{MgCl}_{2}$ and $50 \mathrm{mM} \mathrm{KCl}$ ), $100 \mu \mathrm{M}$ of dNTPs, $0.5 \mathrm{U}$ of Platinum Taq DNA polymerase (Invitrogen). The amplifying cycles followed the steps: $95^{\circ} \mathrm{C}$ for $5 \mathrm{~min}, 30$ cycles $\left(95^{\circ} \mathrm{C}\right.$ for $30 \mathrm{~s} ; 59^{\circ} \mathrm{C}$ for $60 \mathrm{~s}$; $72{ }^{\circ} \mathrm{C}$ for $60 \mathrm{~s}$ ) and $72{ }^{\circ} \mathrm{C}$ for $5 \mathrm{~min}$. Amplified fragments were checked by electrophoresis ( $40 \mathrm{~min}$ at $80 \mathrm{~V}$ ) of $5 \mu \mathrm{L}$ of each reaction product on agarose gels $(1.5 \%)$ containing ethidium bromide. Fragments were visualized under UV light using a Gel Logic system (Kodak).
For restriction fragment length polymorphism (RFLP) analysis, $5 \mu \mathrm{L}$ of each amplified sample was digested at $37^{\circ} \mathrm{C}$ for $1 \mathrm{~h}$ with the appropriate restriction enzymes, following manufacturer instructions (Invitrogen). A $15 \mu \mathrm{L}$ aliquot of each digested sample was electrophoresed $(90 \mathrm{~min}$ at $80 \mathrm{~V}$ ) on a $3 \%$ agarose gel prepared with TEB $1 \mathrm{X}$ (Tris-HCl 89 mM; EDTA $2.5 \mathrm{mM}$; boric acid $89 \mathrm{mM}$; $\mathrm{pH}$ $8.3)$, and ethidium bromide $(5.0 \mu \mathrm{g} / \mathrm{mL})$. Alternatively, electrophoresis was performed on an acrylamide:bis-acrylamide (49:1) 12\% non-denaturing gel, using a SequiGen $38 \times 50$ apparatus (BioRad®). Runs were performed for $60 \mathrm{~min}$ at $80 \mathrm{~V}$ followed by staining with ethidium bromide $(5.0 \mu \mathrm{g} / \mathrm{mL})$. The DNA fragments were visualized as described above.

RFLP analysis was based on our previous study of CSN1S1, CSN2, CSN3 genes in a total of 200 lactating female buffaloes and 360 cows, 60 of each of six breeds (Holstein, Brown-Swiss, Jersey, and three Brazilian native breeds, Gir, Guzerá and Girolanda). Nucleotide sequences had been deposited in GenBank by Otaviano and co-workers, and received the following access numbers: CSN1S1 Bubalus bubalis - EF133464, Bos taurus - EF138810 and Bos taurus indicus - EF138811; CSN2 Bubalus bubalis EF115306, Bos taurus - EF123100 and Bos taurus indicus - EF133460; CSN3 - Bubalus bubalis - EF133463, Bos taurus - EF133462 and Bos taurus indicus - EF133461. These sequences were used to select appropriate restriction enzymes. Only the bovine variants CSN2 Bos taurus -EF123100 and CSN2 Bos taurus indicus - EF133460 were predicted to differ from the bubaline variant CSN2 Bubalus bubalis - EF115306, by a Hae III polymorphism. Nevertheless, we also analyzed the CSN1 and CNS3 polymorphisms.

As predicted, only CSN2 Hae III-RFLP distinguished between the bovine and bubaline casein genes after electrophoresis on a 3\% agarose gel (Figure 1). The intensity of the bands allowed the identification of even very low con-

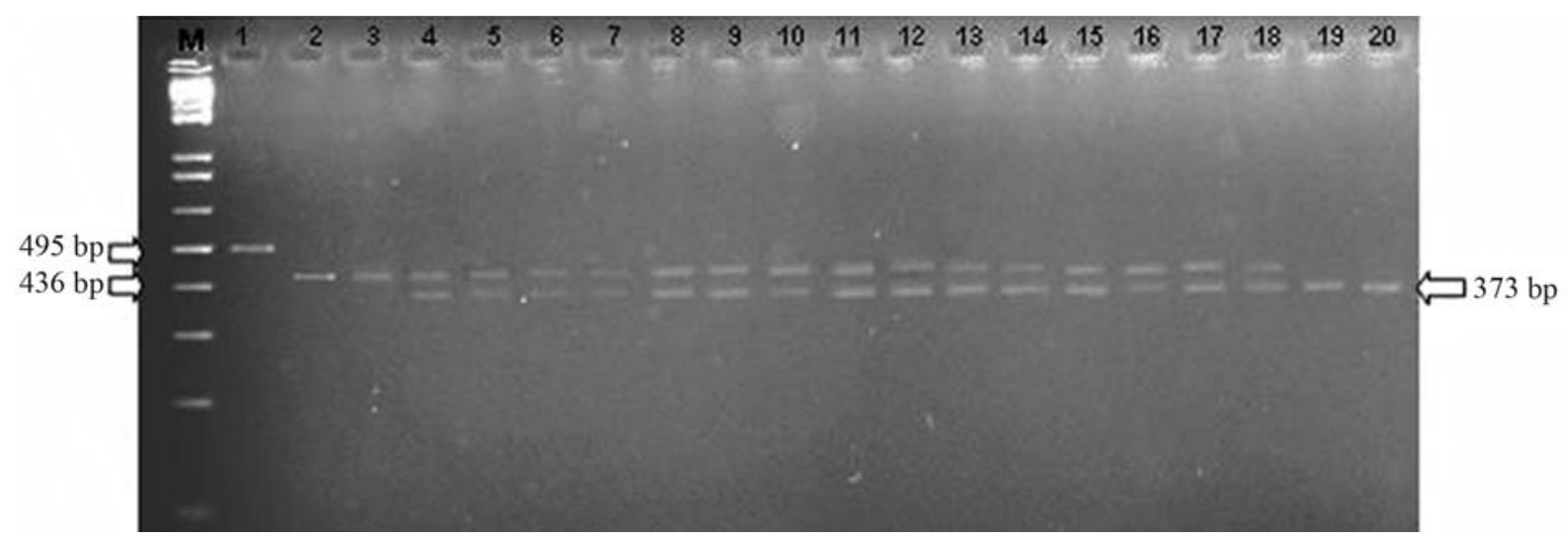

Figure 1 - Hae III-RFLP of CSN2 exon VII allows identifying bovine milk added to bubaline milk in mozzarella cheese. Lane 1, undigested 495 bp PCR product; lanes 2 to 20, bubaline ( $436 \mathrm{bp}$ ) and bovine (373 bp) Hae III-RFLPs obtained from mozzarella cheese containing 0 to $100 \%$ bovine milk; concentrations of bovine milk: $0 \%$ (lanes 2 and 3), 1\% (lanes 4 to 6), 2\% (lanes 7 to 9), $5 \%$ (lanes 10 to 12 ), $8 \%$ (lanes 13 to 15 ), 12\% (lanes 16 to 18 ), and 100\% (lanes 19 and 20). M, 1 kb Plus DNA Ladder. Restriction fragments less than 80 bp cannot be visualized on this $3 \%$ agarose gel (see Figure 2). 
centrations of bovine milk added in the process of manufacturing mozzarella cheese. After electrophoresis on the acrylamide gel system, the bovine and bubaline CSN2 Hae III-RFLPs products could be distinguished, not only by the larger $373 \mathrm{bp}$ and $436 \mathrm{bp}$ fragments but also by the small $59 \mathrm{bp}$ and $63 \mathrm{bp}$ fragments (Figure 2).

We also considered other bovine $C S N 2$ gene variants (described by Bonsing et al., 1988; GenBank accession number X14711) and bubaline CSN2 gene variants (Singh and co-workers, GenBank; accession numbers: A-DQ191172.1, B-DQ191171.1 and C-DQ191170.1) and performed virtual analyses using pDRAW32 software (Figure 3). The bubaline variants showed $95 \%$ sequence similarity with the bubaline variant described here, but they could be distinguished from the bovine variant by the smaller Hae III fragments.

The other RFLPs studied, CSN1S1 (Alu I and Hinf I), CSN2 (Hinf I) and CSN3 (Alu I, Hind III) did not show any difference among bovine and bubaline fragments. The CSN1S1 954 bp fragment resulting from digestion with Alu I generated fragments of 651 and $303 \mathrm{bp}$, and the one resulting from digestion with Hinf I generated fragments of 298, 248, 213 and $195 \mathrm{bp}$ at all concentrations of bovine milk (experiments T1 to T7). The same occurred with the $373 \mathrm{bp}$ fragment of CSN3 digested by Alu I, which generated fragments of 222, 139 and $12 \mathrm{bp}$, and by the enzyme Hind III, which generated fragments of 224 and $149 \mathrm{bp}$. The CSN2 $495 \mathrm{bp}$ fragment,digested by $\operatorname{Hinf}$ I also yielded fragments of 249, 152 and $94 \mathrm{bp}$ in all samples, at the seven bovine milk concentrations. These results confirmed our previous data, showing that bovine and bubaline genes cannot be differentiated by these RFLPs.

Various methods based on DNA analysis have been previously described for identifying bovine milk addition

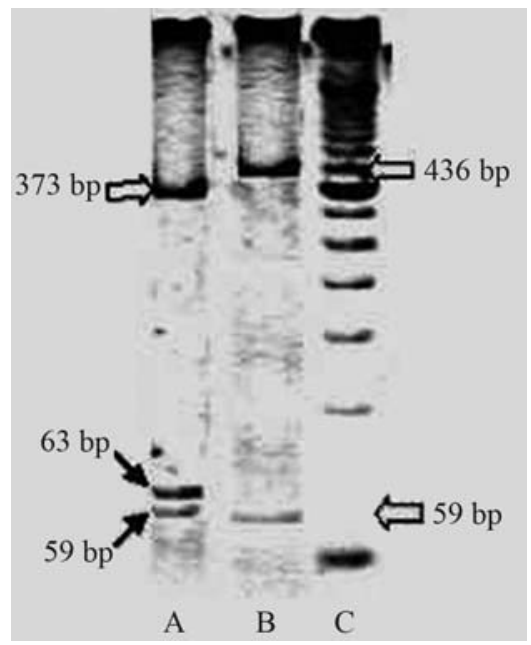

Figure 2 - Bovine and bubaline Hae III-RFLP of CSN2 exon VII visualized after electrophoresis on a $12 \%$ acrylamide gel: A, 373 bp, 59 bp and $63 \mathrm{bp}$ fragments from cheese prepared with pure bovine milk; B, $436 \mathrm{bp}$ and $59 \mathrm{bp}$ fragments from cheese containing pure bubaline milk; C: $50 \mathrm{bp}$ DNA Ladder.

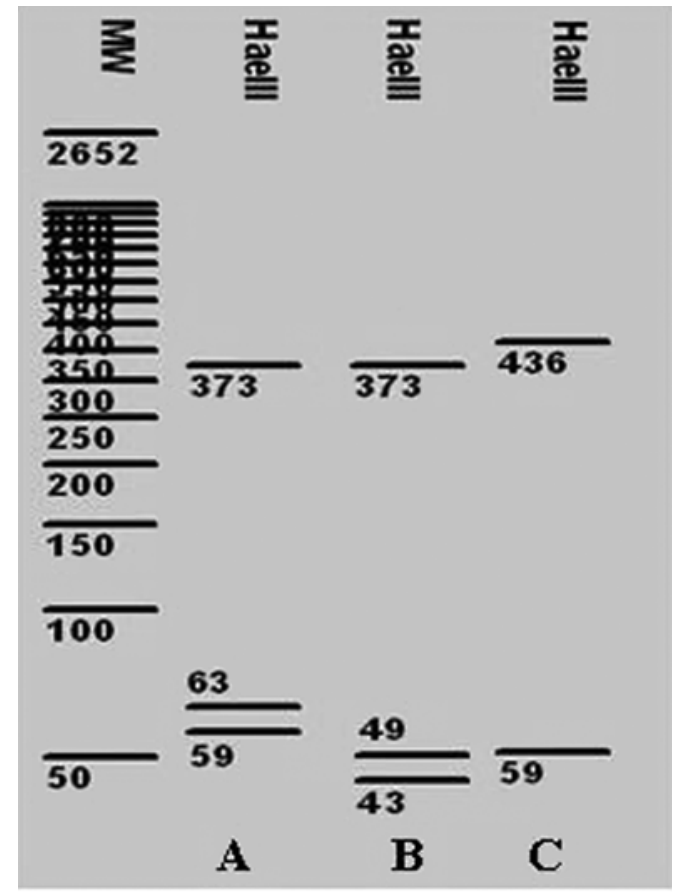

A - bovine variant
B - bubaline variant 1
C - bubaline variant 2

Figure 3 - Virtual analysis of Hae III-RFLP products of the CSN2 exon VII, using the software pDRAW32 on the sequences of (A) bovine and (B) bubaline variants obtained from GenBank; $(\mathrm{C})$ bubaline restriction pattern obtained in this study.

to pure buffalo cheese products. Branciari et al. (2000) reported a PCR-RFLP method on DNA isolated from Italian mozzarella by sequential organic extraction and resin purification. Rea (2001) proposed a duplex-PCR technique to identify bovine and water buffalo DNA in a single PCR assay of milk and mozzarella cheese. Bottero et al. (2002) also developed a duplex-PCR assay and distinguished between fragments of bovine and bubaline mitochondrial cytochrome b genes. More recently, Loparelli et al. (2007) reported a real-time PCR method capable of quantifying bovine milk addition, based on analysis of the bovine mitochondrial cytochrome $b$ gene and the nuclear growth hormone gene.

In this report we show that the Hae III-RFLP pattern of CSN2 exon VII is capable of distinguishing the bubaline and bovine genes, providing a simple method for detecting the presence of bovine milk in mozzarella cheese.

\section{Acknowledgments}

This work was supported by FAPESP (Fundação de Amparo à Pesquisa do Estado de São Paulo, Brazil).

\section{References}

Bonsing J, Ring JM, Stewart AF and Mackinlay AG (1988) Complete nucleotide sequence of the bovine beta-casein gene. Austral J Biol Sci 41:527-537. 
Bottero MT, Civera T, Anastasio A, Turi R M and Rosati S (2002) Identification of cow's milk in "buffalo" cheese by duplex polymerase chain reaction. J Food Prot 65:362-366.

Bramanti E, Sortino C, Onor M, Beni F and Raspi G (2003) Separation and determination of denaturated alpha (s1)-, alpha (s2)-, beta- and kappa-caseins by hydrophobic interaction chromatography in cows', ewes', and goats' milk, milk mixtures and cheeses. J Chromatogr A 994:59-74.

Branciari R, Nijman IJ, Plas ME, Di Antonio E and Lenstra JA (2000) Species origin of milk in Italian mozzarella and Greek feta cheese. J Food Prot 63:408-411.

Chapman HR and Sharpe ME (1981) Microbiology of cheese. Dairy Microb Appl Sci. Publ 12:157-243.

Enne G, Elez D, Fondrini F, Bonizzi I, Feligini M and Oleandri R (2005) High-performance liquid chromatography of governing liquid to detect illegal bovine milk's addition in water buffalo mozzarella: Comparison with results from raw milk and cheese matrix. J Chromatogr A 1094:169-174.

Kuo MI, Gunasekaran S, Johnson M and Chen C (2001) Nuclear magnetic resonance study of water mobility in pasta filata and non-pasta filata Mozzarella. J Dairy Sci 84:1950-1955.

Lopparelli RM, Cardazzo B, Balzan S, Giaccone V and Novelli E (2007) Real-time TaqMan polymerase chain reaction detection and quantification of cow DNA in pure water buffalo mozzarella cheese: Method validation and its application on commercial samples. J Agric Food Chem 55:3429-3434.
Moio L, Di Luccia A and Addeo F (1989). Fast isoelectric focusing of milk proteins on small ultrathin polyacrylamide gels containing urea. Electrophoresis 10:533-535.

Rea S, Chikuni K, Branciari R, Sangamayya RS, Ranucci D and Avellini P (2001) Use of duplex polymerase chain reaction (duplex-PCR) technique to identify bovine and water-buffalo milk used in making mozzarella cheese. J Dairy Res 68:689-698.

Veloso ACA, Teixeira N and Ferreira I (2002) Separation and quantification of the major casein fractions by reversedphase high-performance liquid chromatography and ureapolyacrylamide gel electrophoresis detection of milk adulteration. J Chromatogr A 967:209-218.

Visser S, Slangen CJ and Rollema HS (1991) Phenotyping of bovine milk proteins by reversed-phase high-performance liquid chromatography. J Chromatogr 548:361-70.

\section{Internet Resources}

pDRAW32 Software, www.acaclone.com.br.

GenBank, www.ncbi.nlm.nih.gov.

Associate Editor: Pedro Franklin Barbosa

License information: This is an open-access article distributed under the terms of the Creative Commons Attribution License, which permits unrestricted use, distribution, and reproduction in any medium, provided the original work is properly cited. 